\title{
AN EXPLORATION OF BEGGING STRATEGIES OF BEGGARS
}

\author{
Shahzad Farid \\ Department of Sociology, University of Okara, Pakistan \\ Email: s.farid@uo.edu.pk
}

Sajjad Hussain

Department of Sociology, International Islamic University, Islamabad, Pakistan

Muhammad Zahid

Department of Media \& Communication Studies, University of Okara, Pakistan

\begin{abstract}
The study aimed to develop the typology of begging and beggars in Punjab Province Pakistan. The research employed qualitative research approach. The study used the data of a research project of University of Okara in which 15 districts of Punjab Province were randomly selected. A sample of 45 beggars was selected, who were interviewed by using an interview guide and observation. The study explored that child beggars exploit public emotions of sympathy towards children to earn money. Women beggars target donors and used door to door strategy of begging. The adult beggars used to expose their poverty and exploit religious feelings of people. The study concluded that the general strategies of begging are the exposition of destitution, sympathy gaining, exploitation of emotions and allocating places of begging. The study suggests reinstating the value of social support among families of beggars in relation with their rehabilitation.
\end{abstract}

Keywords: Begging, Beggars' strategies, Child beggars, Women beggars, Disabled beggars.

\section{INTRODUCTION}

Begging has been associated with poverty (Weiss, 2007; Ahamdi, 2010; Gloria \& Samuel, 2012; Onagun, 2016) but it is also a skill which requires training and practice (Tesăr, 2015). Therefore, the exposition of disability, disease, poverty, etc. (Khan, Menka \& Shamshad, 2014) is a strategic process of begging. Previous studies attempted to develop an empirical typology of begging focusing upon the strategies, characteristics and need of beggars (e.g., Namwata, Mgabo \& Dimoso, 2012). One of the interesting types of begging that Ayoob (2019) explored is small merchant beggars, who used to have some goods in their hands and force people to buy from them, while their intentions are only to seek money without selling anything. He also included another type of storyteller beggars, who used to visit the houses for storytelling and ask for monetary help. The other types, which he explored are aggressive, child, elderly, sick/disable, insane and seasonal begging.

Kihara (2017) interviewed 26 individuals on the streets of London and Amsterdam and devised three types of beggars: temporal, continuous and professional beggars. The temporal beggars are those individuals who are at early stage of homelessness. They ask for alms to get rid of their homelessness. The continuous beggars did not approach to the people to ask for money as the temporal beggars do, instead they place themselves anywhere, holding a cup or anything which can carry money. They have been homeless for more than a year. The professional beggars beg because sole source of their income depends on it, which is a crime because chain begging, and beggars' mafia is not legal. The study also indicated that these beggars are often immigrants who attempted to gain sympathy. Abbasi (2020) indicated that professional beggars used such behavior to gain money. However, he identified child begging and genuine begging as two types of begging. The child begging involves begging of a child and the genuine beggars are those who are actually needy and poor.

However, considering the definition of genuine beggars, Kihara's (2017) identified professional, temporal and continuous beggars as genuine beggars because they are in need. Riaz (2019) explored that begging is a structural profession because majority of the beggars have their own houses and having satisfactory lives. It indicates that fake begging also exists, which could be 
professional begging who can fake their physical conditions such as fake disability. One of the interesting categorizations of begging is defined by Namwata, et al., (2012) which is as follows:

i. Beggars on the street

ii. Beggars of the street

iii. Beggars in the street

iv. Beggars of the street families

The first category of the beggars are those people who have their homes, spend most of the time on the street for begging and have contact with their family and relatives. They found that $71 \%$ of the beggars in Tanzania were beggars on the street. The second category of beggars are those individuals who lives in the streets, have no contact with their family and relatives and called homeless people. They found that nearly $18 \%$ of the beggars in Tanzania are beggars of the streets. The third category of beggars are those individuals who are completely abandoned by their families and adapted the lifestyle of beggars. They explored that almost $10 \%$ of the beggars are beggars of the streets. The last category of beggars are the beggars who were raised in the streets. They can be viewed as the professional beggars or the "pure beggars" as indicated by Hirst (2006), because they have family history of begging. Although, Horn and Cooke (2001) identified active and passive beggars in Australia. The study of Abebe (2008) rejected the passive beggar model by arguing that beggars are not passive victims of their circumstances as they are well aware of such predicament. Broadly, Qiao, Chen and Prideaux (2017) identified ten types of begging, which covered almost all forms of begging. These types are as follows:

i. Older adult beggars who wait for donation in the street or mostly spend their time in the streets.

ii. Story-teller beggars, for whom telling a story to a stranger is a source of income.

iii. Passive beggars, the beggars who used to sell small things like hawkers and vendors in the streets.

iv. Such beggars could have aggressive attitude, labeled as aggressive beggars, who somehow force a stranger to purchase their commodity.

v. Disabled beggars are the beggars who expose their disability as a vulnerability to strangers to beg for money, food, etc.

vi. Forcing service beggars are the beggars who begin to provide his/her service to a stranger without asking for, such as car washer or shoe polisher.

vii. Adult beggars expose their poverty to others to take money in return.

viii. Child beggars are the beggars below the age of 18; or the begging that involves children to earn money / alms.

ix. Performance beggars are the beggars who used to entertain people by using their talent such as animal show or puppet show.

x. Buskers are the beggars who used their talent to beg such as guitar playing or dancing on the streets.

Although, these forms of begging cover almost all kinds of begging, but some authors introduced other interesting typologies of begging, such as Brito (2013) focused on begging with the tourist perspective and explored three forms of begging. First, warm-up passive begging in which a child sits at a place while holding a cup in the hands. Second, irritating begging in which a child follows a stranger for a long time, forcing him verbally to give him money. The third form is having fun begging in which a child entertains the tourists for the money. This form is similar to the performance begging of Qiao, et al. (2017).

Similarly, Lu (1999) also identified some interesting forms of begging. The first form is midnight beggars who used to gather around public places such as theaters, cinema, etc. The Second form is bridge helpers, which is similar to the forcing service beggars of Qiao, et al. (2017) who provide services to the strangers without invitation. The third form is following a dog, which is similar to the irritating begging type of Brito (2013), in which a beggar follows a person for long distance to beg. The last form is public lavatory beggars in which a beggar occupies a place in a public lavatory and ask for money to free the space for another person.

\section{DATA AND METHODS}


The study used qualitative research approach to have the enrich and in-depth information about beggars and begging. The sample size of the study is given in table 1. A professional team hired by University of Okara collected the data from beggars using snowball sampling techniques from the randomly selected regions of the Punjab province (see table 1).

Table 1

Selected regions and sample of the study

\begin{tabular}{cll}
\hline Sr. \# & Selected District & Sample size Qualitative study \\
\hline 1 & Lahore & Quantitative data only Urban areas are selected \\
2 & Sialkot & Only Urban \\
3 & Bhakkar & Only Rural \\
4 & Layyah & Only rural \\
5 & Khanewal & Both urban and rural \\
6 & Okara & Both urban and rural \\
7 & Lodhran & Only rural \\
8 & Multan & Only rural \\
9 & Bahawalpur & Both urban and rural \\
10 & DG Khan & Both urban and rural \\
11 & Rajan Pur & Both urban and rural \\
12 & Rahim Yar Khan & Both urban and rural \\
13 & Jehlum & Spatial dimension is selected \\
14 & Rawalpindi & Both urban and rural \\
15 & Attock & Both urban and rural \\
& &
\end{tabular}

The data was collected using the interview guide. The interview guide comprised of basic profile of the beggars, family history of begging and the major causes of begging. The study also used the observation method to collect data which was recorded on the observation notes. The researchers combined the observations of the data collection team and the data of the interview guide to explore the strategies of begging. The qualitative data was analyzed using coding method, in which the initial transcription of the data was codified. The codes were then re-examined to develop important themes which were described using the initial transcription of the study.

\section{RESULTS AND DISCUSSION}

\section{The Art of Exposition: Destitution, Poverty and Skill}

Begging is not just asking for food or money; it is a skill and transmitted from generation to generation by training. Professional beggars are trained in begging because it is their job, they are very keen in understating the human emotions and exploiting them. They knew that in which situation, what words they have to use to provoke the feelings of the targeted donor to earn money. Such linguistic experts have rich cultural and traditional knowledge. It was found that vocal and linguistic abilities are perquisite for beggars, who wander at different places in search of money or food. One of the women beggars told,

"When I see a new couple, I say to them that Allah shall offer you a son. When I see an unmarried couple, I say Allah shall connect you as you are. When I see a disabled child in the hands of a mother or father, I offer my feelings and pray for the quick recovery of the child. When I see a person coming out of a mosque or shrine, I say to them that Allah will answer to your prayers."

Similarly, they are also expert in exposing their vulnerability in a manner that seems true. They gently come to the targeted donor, polity greet him, and then describe their vulnerability while endorsing that they are not beggars, but they were trapped in a situation which forced them to beg for some help. Such beggars are generally occasional beggars and mostly they beg with the company of a family: wife and children. The story they create is usually about losing money, or somebody steal their luggage and they wanted to go back home. One of the respondents said,

"I'm from Rajan Pur, I came to visit shrine of Karma'n Wali Sarkar (Okara). Somebody stole my money, as you can see, I have my wife and children with me. I'm not a beggar, it's an 
immense shame for me that I'm begging you, but I have no other choice. I want to get my family back home safely."

He was also offering his wristwatch to purchase or some stones, which he said are very costly because he purchased them from Iran. His wife also repeated same story of her husband that we have nowhere to go, not even back to the shrine of Karma'n Wali Sarkar because they have lost their money. His husband said that he had forty thousand rupees in his pocket and when I approach to purchase tickets at the railway station, I found that money has gone. Next week, they were observed telling the same story to people at Okara railway station.

\section{The Context of a Place: Reading People}

They also have expertise in finding the best place for begging such as petrol pump, ATM, toll plaza, restaurants, markets, etc. The logic behind attempting to earn money at such places is that the people mostly keep change at these places. At that moment, they rush to that person and ask for the change in the name of Allah. Similarly, people coming at shrines already had in mind to offer something to the shrine or the deserving people outside the shrine. They are well aware of this general psyche of the people. One of the young male beggars. who was standing outside a shrine, covering his head with a religious cap and wearing clean cloths, washed and hygienic, said, "I don't beg, I ask for what already they have for me, it's my share in their pocket." Similarly, a fully covered young girl outside a mosque reported, "I'm not begging to them; I'm requesting them in the name of Allah who give them money for me. They are here to give me my share."

On the contrary, beggars also frequently visit public parks in evening, some of them prefer to place them at the main gate of the parks because there are some small shops and instant food points. They knew that when people eat something, they would have some change which is the best opportunity to earn. When one of the women, who was accompanied by her husband and children, was asked why you don't go to any other place for begging, she replied, “everybody don't keep change in their pockets, they need to get rid of coins. When they eat something, they may have some change for me. It is a good place for earning." The beggars in the parks are very keen observer, they used to watch each man and woman entered in the park. They will follow the guy with a potential to offer some money to them. A woman beggar said that she will respond to the queries of the researcher if her name would be kept secret and she would be given hundred rupees. she said,

"Each night after begging in the market, I came here for rest and earning. I used to sit at this table and watch people keenly who walk or sit here ... I look for the specific people such as young couple, a couple with children, newly born babies... Last night, a newlywed couple came here. You know, every new couple desires a child. I went to them and said, 'Allah will give you a beautiful, handsome and obedient son, please help me.' They gave me one hundred rupees and said to repeat the prayer. I repeated it."

Apart from selecting a place and reading the psyche of public, they are also well trained in reading the collective behavior. They know regarding peak times of earning through begging such as Muharram, Ramadan, Wedding, 12 Rabi ul Awal, Eid ul Fitr and Addha. These are the seasons when they went together with their whole family for begging including children and working members. If someone from the family is on a job e.g., garbage collection, he or she would leave that job temporarily or take leaves. They would distribute the places according to the available human resources of the family. Such as a male head of a family said,

"We are six family members, my brother, my wife, and three children. In Ramadan, if we gather at one place, we cannot earn much, therefore, I send each person including my children to the big mosque of the city. Each day, we rotate our positions, ... In this way, we collect enough money for ourselves."

When they came to know that a rich person is about to distribute food, clothes, money, etc., they all temporarily leave their allocated positions and rush to that place. After collecting money, they came back to the same allocated places. They have knowledge about who is going to distribute food, money or clothes as there are some people who used to offer alms to the deserving people every year. On contrary, they shift a person to another place if he had not been earning well from the allocated place. A young beggar said, "...during Ramadan, my father sent me to the house of the Malik sab, because I was not earning well outside the mosque." 
Similar is the case in rural areas, where in addition to these peak seasons of begging, there are two more events where they earn potentially, mostly in the form of raw food. These two seasons are the harvesting time of Fasl e Kharif and Fasl e Rabi. The former season is between June and October (summer season), and the latter is the season between November and April (winter season). After the harvesting, each farmer offers a share of the harvested crops to the poor, which they consider Islamic obligation. Therefore, the beggars already planned that where they should go for asking the share. Some of them repeatedly going to same houses for their share and the peasants already know that which beggar will come for the share. One of the middle-aged beggars said,

"Me and my wife are harvesters, but this job cannot give much money because we can harvest crops only in the seasons of harvesting. When there is no work for us, I ask people to help me. I know that who has good crops and enough money to help me. Each year I go there for food. Malik sab knows that I'll come, he already keeps my share aside."

\section{Spatial Distribution and Monopoly}

Beggars have fixed places and distributed territories for begging. It is a community level strategy of beggars. They have defined border lines for each family who is responsible for earning and securing that place: they are responsible for not allowing other beggars to enter the place. They sent family members, including children, to that defined places and when all the family members come back home at night, they collect money from everyone. This is a defined process among beggars that the collected money or food will be given to the head of the family, who is usually a male.

The conflict exists between the professional beggars and other beggars who are begging due to their destitution and vulnerability. The defined territory is the responsibility of the person who has allocated this part of the land for begging, so he has to secure his land from other beggars. He would not allow other beggars to beg at his area because it is his source of income. A beggar, who has given a territory usually visits all the shops, houses, small markets in that area on the regular basis. The residents also become familiar with him and after spending some time in the area, the beggar observe and enlisted those houses or shops that provide him money or food without asking. Each day when a shopkeeper opens his shop, he starts his day with offering some money to beggars with the belief that by doing some charity, he will earn more. Similarly, people at homes often give a share of their breakfast to the beggars because they do not want to hear any curse in the beginning of the day, or they wanted to commence the day with blessing through charity.

Other than territory, some of the beggars have a fixed place for their earning. There has always been a competition on territory distribution because number of beggars are increasing in the country. It is difficult for one person to secure any place for begging; therefore, they go at one place in groups usually two or three families along with their children. By using this strategy, they secure their dominance over the place and over other beggars at the same spot. Secondly, they secure higher probability of higher income because they are greater in numbers.

Beggar children do not directly beg for money. They pretend selling disposable or cheap products such as books for children, disposable cups for tea, clothes for washing cars or bikes, etc. At first, they tried to sell their product, if the targeted person does not purchase any product, they begin begging for money and requesting for helping them by telling stories about their fasting or hunger. They use different means of exploiting the people emotions towards poverty or destitution. They know people have soft corner for kids, so they place children at begging spots. These children are well trained, and they would not easily give up until they get money. They generally adopt two strategies for successful begging. First, they would keep insisting to give them money or to purchase from them. Second, chasing the donor within the defined place. The later strategy is an alternative to the first one. If the first strategy fails, the second will be executed. Considering this the final move, they will not easily give up and keep insisting to help them.

Another strategy employed by beggars is to provide their services to people. It is to be noted that not all the beggars use this strategy as there are some lowest cadre jobholders who genuinely want to work to earn bread such as the washroom cleaner, sweeper, etc. These beggars usually wander at the bus stops, motorway interchanges, railway stations, etc. They would provide their services without demand. At the motorway interchanges, these beggars usually approach vehicles and clean the front glass of cars. When the owner comes back, they rush to him asking for money in return of the 'not demanded' services. Similar beggars are found at the railway stations, who would start 
polishing shoes and would ask for money even when you are not willing to take their services. In case they remained fail in earning the money from their fixed spots, which is the very rare case, they would move to other places which are not claimed by any other beggar, or the place the beggars have left after earning. These are usually the places like markets, parks, and other public places. One of the teenage beggars reported, "Haji sab, I earn nothing today from the railway station, I came in this market tonight for earning, I can clean your motorbike. Please give me one hundred rupees as I want to buy 'Atta' (food) for my mother and younger sister. They are starving."

However, not all the beggar families involve their children in begging. Some of them select a disabled person for begging. There are some real disabled beggars who cannot walk around for begging. Therefore, they place a disabled family member at a fixed place and pick him/her up at late night and collect money of his earning. A young disabled beggar at the road of Okara city has fixed a place for himself. He did not ask for money to anyone rather he used to lay down on his chest while shaking his heads up and down persistently. His position is like being in 'sajada' while laying down and shaking head up and down continuously. He also put a box of charity near him. It was observed that every dawn, he came to the footpath of the road and remained in that position. He was never observed of eating or drinking anything but shaking his head. However, in the late night, a person picked him up on a motorbike because he was unable to walk by himself.

However, there is an alternative strategy for disabled beggars, which is to take him/her around the streets or different places accompanied by any physically fit beggar. The accompanied person is either a mothers of a child, or sister of a brother, or husband of a wife or vice versa. It was observed that majority of the beggars have disability related to bones dislocation, broken legs, paralysis, etc., (Wamisho \& Menore, 2009). If a child is disable, the mother usually carries him/her on his chest or back.

In the case of a young disabled person, beggars put him/her in a wooden stroller or a pram. One of the beggars' mothers said, "he is unable to walk since birth, I carry him in this wooden stroller and ask for money in his behalf as he cannot say it by himself." Similarly, a group of disabled elderly people was observed in Multan, who used to carry themselves in wooden pram by using a wooden box to push the pram. This group used to recite Sufi songs and Naat (singing the admiration of Muhammad SAW). They do not ask any person to help them. Recitation of Naat, their disabilities and their appearances are the symbols that speaks for them. These symbols give the messages to the people that we need help and we are asking for money, although all they do is reciting Naat. We managed to speak to them and asked about them. They all directed us towards a person who was the head of this elderly group of beggars. The leader said,

"We all are disable and couldn't walk. We have no families either...but the important thing is that we need to survive and for that we need food and money... I was already a beggar, so I took some homeless disabled people with me. We formed a group for begging."

Table 2

The description of the strategies of begging

\begin{tabular}{ll}
\hline Strategy & Remarks \\
\hline Wandering around & $\begin{array}{l}\text { All professional beggars use this strategy. They wander } \\
\text { around and collect anything that people offer including } \\
\text { clothes, food, money, shoes, etc. }\end{array}$
\end{tabular}

Fixing a place/spot/house

Exploiting emotions

Distribution of territory

Deceptive play
All professional and occasional beggars use this strategy. They fix a place and place one of the family members (usually a child) there to earn.

This is a skill that works better for children. Therefore, beggars teach children how to exploit public emotions towards children to get money.

All professional beggars use this strategy. This is community level strategy in which a community of professional beggars allocate cities as a fixed territory of begging. 
The skill usually exploits the religious feelings of the public.

Providing Services

Exposition of aging

Exposition of destitution / poverty

Chasing donor

Selling cheap products

Begging seasons

Entertaining the public

Targeting donor

Door to door

Child sympathy

Earning from government
It is a fixed place strategy usually used as a part- or full-time begging strategy in which a beggar provides his services to an expected donor without his/her demand such as washing the front glass of car or polishing shoes.

Only aging people use this strategy regardless of being a professional beggar. They exploit feelings of public towards elderly people.

All beggars use this strategy. Beggars are skilled in exaggerating their poverty, destitution and vulnerability to the public.

Only children are trained in this strategy of chasing people while insisting to help them.

Children, teenager, women and elderly use this strategy, but it is not conditioned with fixed place. Beggars sell a cheap product to the public. In case it was not purchased, they ask for money.

It is a community level strategy. However, some professional beggars do it in person as they have fixed houses for taking their share

It is a skill mostly employed by the male head of a family. The instruments that a beggar used are usually musical instrument. It also involves performing a play to children or showing amusing movements of animals such as monkey or bear.

It is a strategy of women with rich cultural understanding or psychological understanding of people. It involves reading the situation of donor and use effective communication skill to get money from them.

It's a regular strategy of begging in which beggars ask for money while knocking each door of a block.

It's a strategy of beggar parents who used their vulnerability to feed children.

It's an opportunity that the beggars never failed to exploit. Whenever the government announces a helping program for poor, they tried their best to earn from it.

\section{The Verbal and Non-verbal Begging Play}

Two of the strategies, now rarely used, are deceptive play and entertaining the public. The former strategy involves the higher cultural, social and psychological knowledge of a community in which it is performed. Usually, this strategy is used in the rural areas where cultural celebrations took place such as Besakhi Mela, a celebration follows harvesting of crops. During such celebration, a group of trained people came in the Mela in order to show their play to the people. They set their luggage and local instruments in a street or a place which is not crowded. They perform play at three stages which is very strategic. At the first stage, they set up all their logistics in a crowed place, which must be at the corner of a street. During the show, they would set up a very interesting story about sex timing, solving marital problems, controlling the wife, etc. The leading speaker would not explain that how it can be done rather they just described like, "I have found the solution of your problems, I will give it you without any cost, just listen to me very carefully." As they set the agenda, a person comes to the place and abuse him while saying that this all is a deception and illusion and take your luggage and 
move away from this public place. After forcing the leading speaker too much, he got the attention of the spectators and then he tells them to go into this street because these people want to listen you, "For the sake of these venerable people, I allowed you to carry on your show in the street." By using this technique, he pushed all the gathered crowd into a street where they give impression to people that they are safe because no policeman or other law enforcement agency can trace them down there.

After entering the stage, the leading speaker again starts the show but before explaining the solution, he would show off his power, which is the second stage of the play. He shows people that how he could put fire into his luggage or how he could control the minds of people, etc. He would ask for a volunteer from the spectator to come forward. A person suddenly jumps in and says, I volunteer myself. This person is actually part of the team. The leading speaker orders him to close his hands, the volunteer follows the instruction. The leading speaker starts reciting something and hand over some puffs to the volunteer. After reciting and puffing, the leading speaker orders the volunteer to open his hands. His first magic line was, "see, he is completely in my control now." The volunteer cannot open his hands, he struggled to open them, but all struggles went in vain. Suddenly, he fell down and started shaking his whole body. This moment creates a hysteria. All crowd get frightened about the magical powers of the speaking leader. At this moment, he asks all crowd to throw money before him and forced them to empty their pockets and do not left a single penny or otherwise you will face the same fate. When some of the spectators throw money before him, suddenly another young man, with long beard, wearing religious dress and cap appears on the scene.

He halts spectators to give him money and calls him a deceptive person. He announces that you have no power, and you are fake everything you have done by adding that if you really have such evil powers, then "try me." The leading person laughs at him and warn him. The religious person insists. The third and the final stage begins. The leading person enchants something while instructing the religious person closing his both hands. After enchanting, the leading speaker commands to open the hands. The religious persons open his hand and smiles. He asks him to take another try. The result stays the same and the religious person is able to again open his hand. This time, the religious person divulges that you, in fact, are using black magic, but "I'm master of Noori magic (spiritual magic) and your spells cannot work on me." On the contrary, "my magic will vanish you."

Meanwhile, the religious person recites some Quranic verses and throw something imaginative on the luggage of the leading speaker and the luggage catch fire. He again recites some Quranic verses and puffs on the man who is struggling to open his hands, which works, and the man is able now to open his hands. As he opens his hands, with much joy and reverence, he starts kissing the feet of the religious man. This creates a feeling of a reverence among all the spectators. It positively influences them as they were all afraid of the leading speaker who attempted to snatch their money by force.

At the same moment, the religious person again recites something and throw something imaginative on the leading speaker. Resultantly, the speaker closes his hands and fell down like he is having an attack of paralysis. At this moment, the religious person looks at the spectator who are already under the influence of his spiritual power, and says,

"You all are venerable men. I knew this with my spiritual powers, inherited from my spiritual teacher. The teacher ordered me last night to arrive exactly at this place to save all of you...I request you all please help me to build a mosque in the name of my teacher, ... After giving money, you are not allowed to stand here anymore, just walk away, don't turn back, in case you may burn by reversing the spell I casted on them."

Using this strategy once in a week at different places, they earn more than the monthly income of a regular beggar. One of our focal persons managed to have a meeting with the leading speaker who told this whole story.

There is another strategy of begging by a play, which involves exposing the talent instead of deceiving people. It is called begging by talent. It is one of the most talented and sophisticated way of begging. It sometimes is known as street talent and street talent is not begging, so they should not be labelled as street beggars. I called it entertaining the public strategy of begging. It is evidenced by Tesăr (2015) that the begging is a form of work, which requires training and practice and even change in cultural activities. She also rejected the hypothesis of begging associated with charity. Her study focused upon the gypsy group of Romanian in Italy and found that the view of such beggars is not 
associated with poverty, unemployment, etc. rather it is a performative act embedded with learning of skills and bodily activities.

The entertaining strategy is a non-verbal begging. The verbal codes that often used in streets e.g., praising and blessings along with voluntary/monetary help seeking, are not used in non-verbal begging. In this strategy, a beggar performs his/her talent in the streets such as lawn, malls, grounds, etc. especially at a crowded place where she/he can catch attention of the audience and does not verbally ask for help. It is the talent, which symbolically conveys a message to audience to help $\mathrm{him} /$ her out. Such form of begging is mostly implied in European and American countries.

In Pakistan, a beggar who aims to entertain the public usually use animals conditioned with a wooden stick e.g., monkey, goat and bear. It's like a puppet show but the puppet is an animal. In the local language, he is known as Madari (the show master) who trained animals to perform certain acts. Most commonly, the monkeys are trained to perform the act. The Madari holds a stick in his hand and speaks or interpret the actions of the monkey. He also verbally orders the monkey while using the specific movements of the stick to act in a certain way. At the end of the show, he orders the monkey to lay down on the land and to put hands on the belly. Then, he interprets this posture of the monkey as the monkey has not fed since morning and he also has no money to purchase food for him. The monkey is requesting you to pay him some gratitude of his performance and give money in your capacity. The Madari actually speaks for the monkey for begging because he has the to perform the whole show. It is same as a guitar of a street guitarists, speaking for his master and asking artistically and musically to help him with some money.

Some of the beggars in the streets used to entertain the public by playing a musical instrument such as a 'teen tara', harmonium, drum, etc. These beggars walk across the streets while singing and reciting the Naat. Sometimes they knock on the doors and keep walking. The people come out of their houses and pay something to them. It was found that begging is a part time job of most of the beggars with this talent because they used to perform on musical shows especially in Qawali and with local dancers. The dancers are usually females or third gender. One of the Harmonium players, who was begging in the streets reported, "I'm a qawal, but, unfortunately, I hadn't had a show in this month. Therefore, I am showing my talent in the streets for money."

On contrary, there are some professional beggars who learned a musical instrument for begging. One of the elderly beggars who plays teen tara said, "I have good vocal, and I can sing as I learned to attract people. One day, one of the strings of my teen tara was broken and I came out for begging without playing it. I earned less than a quarter of what I have been earning with teen tara." Nevertheless, all the strategies that the beggars developed and adopted are working well for them and they are earning from them. In table 2, all the explored strategies are given and briefly described.

\section{CONCLUSION}

The study focused upon the begging with the perspective of beggars in order to get insight of the issue. The study explored that the beggars used various strategies for begging that could be effective for their income generation process. It was found that the strategies of begging vary according to the age of the beggars such as children used the emotional exploitation of the donors while chasing them and providing forced services or sell cheap products with intention of begging. Similarly, other beggars such as adult beggars used to exaggerate their poverty or exploit religious feelings of people in the distributed territories. Women beggars used their children as a token of sympathy to earn money. They mostly target donors and employ door to door begging strategy. Furthermore, the general strategy of begging for all types of beggars is exposition of destitution, sympathy gaining, exploitation of emotions, allocating and distributing places and earning from government welfare programs.

The study suggests reinstating social support value because this value is a defensive wall against increasing begging among elderly people. On the other hand, the rehabilitation and capacity building are not recommended as this has not been found an effective strategy of stamping out begging because beggars inherited begging and it is also their habit. Therefore, they need social support either from community, family or from government. However, providing financial support would not enable them to earn livelihood through respectable ways rather they would become state supported beggars. Therefore, the study suggests combing solution considering the nature of each case. 
Those beggars who inherited begging need to rehabilitate with the provision of small-scale businesses, which required to be evaluated daily. However, those vulnerable elderly beggars who were begging due to lack of social support required to provide governmental support, such as they could be admitted in elderly homes. They should not be rehabilitated, nor they should be provided capacity building trainings because an aged person only requires social support.

ACKNOWLEDGEMENT: The authors gratefully acknowledges the permission of University of Okara for using the data of the research project, conducted in compliance of the Lahore High Court Order (Writ Petition No. 9882/2005) and Additional Secretary Law, reference 11636.

\section{REFERENCES}

Abbasi, A.A. (2020). Begging -types -A thorough repot with suggestions. Retrieved from https://www.hardhour.com/begging/

Abebe, T. (2008). Earning a living on the margins: begging, street work and the socio-spatial experiences of children in Addis Ababa. Geografiska Annaler: Series B, Human Geography, 90(3), 271-284.

Ahamdi, H. (2010). A study of beggars characteristics and attitude of people towards the phenomenon of begging in the city of Shiraz. Journal of Applied Sociology, 39 (3), 135-148.

Ayoob, S.M. (2019). Beggary in the society: a sociological study in the selected villages in Sri Lanka. Journal of Xi'an University of Architecture \& Technology, 11(12), 1725-1736.

Brito, O. (2013). Definitional paradox and legal heterogeneity: Towards a comprehensive and operational definition of begging. Asian Social Work and Policy Review, 7, 228-241.

Gloria, O.E., \& Samuel, A. (2012). The prevalence of street begging in Nigeria and the Counseling Intervention Strategies. Rev. Eur. Stud., 4(77).

Hirst, P.Q. (1972). Marx and Engels on law, crime and morality. Economy and Society, 1(1), 28-56,

Horn, M., \& Cooke, M. (2001). A question of begging: A study of the extent and nature of begging in the city of Melbourne. Retrieved from https://dokumen.tips/documents/horn-cooke-2001-aquestion-of-begging-a-study-of-the-extent-and-nature.html

Khan, J. H., Menka \& Shamshad. (2014). Socio-economic Causes of Begging. International Research Journal of Human Resources and Social Sciences, 1(3), 37-52.

Kihara, T. (2017). Street Debater- Designing social alternative to begging. Retrieved from https://medium.com/@kihapper/street-debater-designing-social-alternative-to-begging485db4afcc89\#: :text=Through\%20these\%20contextual\%20interviews\%2C\%20I,or\%20hagg ard\%2C\%20holding\%20a\%20cup

$\mathrm{Lu}, \mathrm{H}$. (1999). Becoming urban: Mendicancy and vagrants in modern Shanghai. Journal of Social History, 33(1), 7-36.

Namwata, B.M., Mgabo, M.R., \& Dimoso, P. (2012). Categories of street beggars and factors influencing street begging in central Tanzania. African Study Monographs, 33(2), 133-143.

Onagun, A.I. (2016). Relationship between street-begging and poverty in Ilorin Emirate, Kwara State, Nigeria. International Journal of Health Economics and Policy, 1(1), 6.

Qiao, G., Chen, N., \& Prideaux, B. (2017). Understanding interactions between beggars and international tourists: The case of China. Asia Pacific Journal of Tourism Research, 22(3), 272-283.

Riaz, S. (2019). Women Begging in the light of Islamic Teaching. Journal of Islamic Studies, University of Karachi, 21(1).

Tesăr, C. (2015). Begging: Between charity and profession. Reflections on Romanian Roma's begging activities in Italy. In Tauber, E. and Zinn, D. (eds), The public value of anthropology: Engaging critical social issues through ethnography (pp. 83-111)

Wamisho, B.L., \& Menore, L.H. (2009). Begging on the streets of Addis Ababa: an impact of musculoskeletal disability. East and Central African Journal of Surgery, 14(1), 103-108.

Weiss, H. (2007). Begging and almsgiving in Ghana: Muslim positions towards poverty and distress. Nordiska Afrikainstitutet, Research Report 133. Sweden: Elanders Gotab AB, Stockholm. 